\title{
Plague and the Fall of Baghdad (1258)
}

\author{
Nahyan Fancy ${ }^{1 \star}$ and Monica H. Green ${ }^{2}$ \\ ${ }^{1}$ Dept. of History, DePauw University, 7 E Larabee St., Greencastle, IN 46135, USA \\ ${ }^{2}$ Independent Scholar, Phoenix, AZ, USA \\ ${ }^{\star}$ Corresponding author. Email: nahyanfancy@depauw.edu
}

\begin{abstract}
The recent suggestion that the late medieval Eurasian plague pandemic, the Black Death, had its origins in the thirteenth century rather than the fourteenth century has brought new scrutiny to texts reporting 'epidemics' in the earlier period. Evidence both from Song China and Iran suggests that plague was involved in major sieges laid by the Mongols between the 1210s and the 1250s, including the siege of Baghdad in 1258 which resulted in the fall of the Abbasid caliphate. In fact, re-examination of multiple historical accounts in the two centuries after the siege of Baghdad shows that the role of epidemic disease in the Mongol attacks was commonly known among chroniclers in Syria and Egypt, raising the question why these outbreaks have been overlooked in modern historiography of plague. The present study looks in detail at the evidence in Arabic sources for disease outbreaks after the siege of Baghdad in Iraq and its surrounding regions. We find subtle factors in the documentary record to explain why, even though plague received new scrutiny from physicians in the period, it remained a minor feature in stories about the Mongol invasion of western Asia. In contemporary understandings of the genesis of epidemics, the Mongols were not seen to have brought plague to Baghdad; they caused plague to arise by their rampant destruction. When an even bigger wave of plague struck the Islamic world in the fourteenth century, no association was made with the thirteenthcentury episode. Rather, plague was now associated with the Mongol world as a whole.
\end{abstract}

Keywords: Yersinia pestis; Historical chronicles; Islamic medicine; Miasmatic theory; Mongol Empire

In 1977 and 1978, historians John Norris and Michael Dols engaged in a heated debate about the geographic origin of the Black Death, the plague pandemic that devastated the Middle East, North Africa and Europe in the fourteenth century. According to Norris, the wave of plague that moved northward across the lands of the Golden Horde (what is today southwest Russia, north of the Caucasus Mountains) in 1346, and southward towards Tabriz and Baghdad in 1347, emerged out of the Caucasus Mountains themselves. According to Dols, the Black Death's origins were much further to the east, in Central Asia. Norris argued there was no evidence that plague moved due west across the steppe from a region in western Kyrgyzstan, where plague was reported in 1338-9, over to the territory of the Golden Horde by 1346. Dols, in contrast, both in his direct debate with Norris and in other writings, insisted on taking at face value the testimony of Arabic writers at the time of the Black Death who tied the presence of plague in the Black Sea and Mediterranean regions to events further east. ${ }^{1}$ What could be called the 'rapid transEurasian transmission thesis' was also adopted by William McNeill in his Plagues and Peoples, which

\footnotetext{
${ }^{1}$ John Norris, 'East or West? The Geographic Origin of the Black Death', Bulletin of the History of Medicine, 51, 1 (1977): 1-24; Michael W. Dols, 'Geographic Origin of the Black Death: Comment', Bulletin of the History of Medicine, 52, 1 (1978), 11213; John Norris, 'Response', op. cit., 114-20. Dols addressed the origin and route of the Black Death at more length in other works: Michael Dols, trans., 'Ibn al-Wardī's Risālah al-naba' 'an al-waba', a Translation of a Major Source for the History of the Black Death in the Middle East', in D. K. Kouymijian (ed.), Near Eastern Numismatics. Iconography, Epigraphy, and History: Studies in Honor of George C. Miles (Beirut: American University of Beirut, 1974), 443-55, 448; Michael W. Dols, The Black Death in the Middle East (Princeton: Princeton University Press, 1977), 42-53.
}

(C) The Author(s), 2021. Published by Cambridge University Press. 
appeared (unbeknownst to Norris and Dols) in 1976. Although McNeill's claims about the Black Death's origins in east China proved unpersuasive, for the next 40 years, the assumption remained that plague had covered at least $3000 \mathrm{~km}$ between Central Asia and the Crimea in about a decade's time. In other words, all these theories placed plague's westward movements squarely within the fourteenth century. ${ }^{2}$

Recent findings combining evidence from genetics, ecological studies of plague and documentary sources suggest that both Norris and Dols were right, but only partially. They both correctly identified geographic regions involved in plague's late medieval dissemination, but they were describing two separate phases in plague's westward transmission. We know now that the bacterium Yersinia pestis has been distributed multiple times across the Eurasian steppe since the Late Neolithic. There are strains alive today that first emerged in the Bronze Age. However, the strain of plague that can now be palaeogenetically documented in Black Death gravesites from fourteenth-century Europe has been shown to be very closely related to current-day strains from Central Asia, specifically in the Tian Shan mountain range of what is present-day Kyrgyzstan. This finding vindicates the perspective of Dols (and the early twentieth-century Chinese plague ecologist, $\mathrm{Wu}$ Liande before him) that the Inner Asian Mountain Corridor was a long-term home of plague. But Norris also seems to have been right: there is still no evidence, save for the claims of a handful of late medieval commentators (whose testimony we will address below), that plague was suddenly transferred across the steppe from Central Asia all the way to the Caucasus in the fourteenth century. ${ }^{3}$

Evidence from genetics (what Green has called 'the biological archive') and a re-reading of documentary sources instead suggests that plague moved across Central Asia, not via the northern steppe, but through lands making up modern Iran and Iraq, and that it did so in the thirteenth century, not the fourteenth century. ${ }^{4}$ Building on work done on Song China by Robert Hymes, who argued that the Mongols brought plague into China perhaps as early as 1218, Green has gathered evidence that the Mongols moved plague out of a long-term reservoir in the Tian Shan mountains into several new ecological landscapes. ${ }^{5}$ The spillover event that caused this 'Big Bang' - so termed by the geneticists who originally documented a sudden divergence of $Y$. pestis into four new lineages prior to the Black Death began perhaps as early as the Mongol encounters with the Turfan Uighurs around 1209 and the Mongol conquest in 1218 of the Qara Khitai empire, whose region stretched from east of the Tian Shan mountain range to Khwārazm (present-day Kazakhstan). From this central location, Green argues, the Mongols then spread the bacillus out in several directions: east to China, west to the Caucasus and north to southern Siberia and Mongolia itself, resulting in several plague outbreaks.

One of these outbreaks was connected to the Mongol siege and conquest of Baghdad in $1258 .{ }^{6}$ Surprisingly, post-Black Death chronicles and plague treatises from the western Islamic world, written barely a century later, fail to acknowledge this thirteenth-century outbreak. ${ }^{7}$ This erasure is particularly significant because, unlike the Chinese tradition, Arabic already had specific vocabularies and frames of reference to talk about plague, its physical manifestations and its cultural significance. Plague was actively

\footnotetext{
${ }^{2}$ William H. McNeill, Plagues and Peoples (Garden City, NY: Anchor Books, 1976); McNeill suggested that plague had been dislodged out of the Himalayas in the thirteenth century, but remained confined to China. See Monica H. Green, 'The Four Black Deaths', American Historical Review, 125, 5 (2020), 1601-31.

${ }^{3}$ For a transformative new interpretation of the traditional story of plague transmission from the Golden Horde to the Genoese and Venetian colonies on the Black Sea, see Hannah Barker, 'Laying the Corpses to Rest: Grain, Embargoes, and Yersinia pestis in the Black Sea, 1346-1348', Speculum, 96, 1 (2021), 97-126.

${ }^{4}$ Green, op. cit. (note 2).

${ }^{5}$ Robert Hymes, 'A Hypothesis on the East Asian Beginnings of the Yersinia pestis Polytomy', The Medieval Globe, 1, 1-2 (2014), 285-308; Green, op. cit. (note 2). We thank Professor Hymes for alerting us (personal communication) to his subsequent findings that plague may have appeared in China as early as 1211 or 1213.

${ }^{6}$ Mona Hassan, Longing for the Lost Caliphate: A Transregional History (Princeton: Princeton University Press, 2017), 47, noted that plague had played a role in the catastrophe, an observation never previously noted in modern plague historiography.

${ }^{7}$ A. von Kremer and Michael Dols both noted in passing that an epidemic or even plague was reported in Syria in 1258, but they never delved into the extensive chronicle reports on the outbreak: A. von Kremer, Ueber die grossen Seuchen des Orients nach arabischen Quellen (Vienna: Kaiserliche Akademie der Wissenschaften, 1880), 62-67; Dols, The Black Death, op. cit. (note 1), 34 .
} 
circulating around the Mediterranean basin when Islam arose in the seventh century, and by the ninth century, the disease $t \bar{a} \bar{u} \bar{n}$ (plague) had become central to religious discussions on contagion, martyrdom and even attitudes towards jihad. At the same time, $t \bar{a}^{-} \bar{u} n$ also became a fixture in medical works, especially while discussing swellings and fevers. ${ }^{8}$ As Lawrence Conrad documented in the 1980 s for religious commentary traditions, and Fancy documents for medical commentary traditions in a forthcoming piece, there was a clear upsurge in learned discourse in Arabic about plague in the latter half of the thirteenth century. ${ }^{9}$

In erasing even the memory of the 1258 plague outbreak, writers of the fourteenth century created a narrative of western Eurasia's Black Death experience that shaped the historiography of the pandemic both in the Islamic world and in Europe down to the present day. ${ }^{10}$ Several of these writers introduced the idea that the Black Death originated in the 1330s in far-away east Asia, mentioning North China (areas around Beijing) and South China (areas around Quanzhou) explicitly. Thus, even though these accounts allowed modern historians to associate the Black Death with the Mongol Empire, the exclusion of the thirteenth-century outbreak(s) from fourteenth- and fifteenth-century accounts erased evidence that could have intimated to historians why 'plague thinking' took on a new dimension in Arabic writings more than half a century before the devastating outbreaks of the 1340s.

In the present study, we aim to do four things: (1) to gather together, for the first time, the extensive body of evidence in Arabic historical chronicles attesting to the presence of a plague-like disease in Baghdad, Damascus and surrounding regions in the aftermath of the Mongol conquest of Baghdad in 1258; (2) to document the contemporaneous shifts in thinking about plague that can be discerned in the writings of physicians and theologians; (3) to explain how the chroniclers could classify the disease outbreak as only an 'epidemic' ( $w a b \bar{a})$ for Baghdad itself but as plague ( $t \bar{a} \bar{u} \bar{u})$ for Damascus and other parts of Syria, a conceptual framing that flags the increasing significance of miasmatic thinking and (4) to suggest why these disease events in western Asia after the Fall of Baghdad, which is universally understood as a cultural turning point of cataclysmic proportions, fell out of Arabic historiographical traditions from the mid-fourteenth century onwards.

\section{Rediscovering Baghdad}

In 2007, scholars surveying the extant corpus of writings of the thirteenth-century polymath, Qutb al-Dīn al-Shīrāzī (d. 1311), announced the discovery of an autograph manuscript containing a hitherto unknown work: Akhbār-i Moghūlān (Mongol News). ${ }^{11}$ Published in its original Persian in 2010, and translated into English in 2018, Mongol News recounts how, at the siege of Baghdad in 1258, 'Pestilence [waba] struck and many people died'. The level of fatalities was so extreme that normal burial practices could not be maintained; instead, bodies were thrown into the Tigris River. Most of the Mongol army also became sick. ${ }^{12}$ Unaware of the discovery of this text, the most recent historian of the Fall of Baghdad,

\footnotetext{
${ }^{8}$ On religious and legal traditions, see Justin K. Stearns, Infectious Ideas: Contagion in Premodern Islamic and Christian Thought in the Western Mediterranean (Baltimore: Johns Hopkins University Press, 2011). On medical thinking, see Nahyan Fancy, 'Knowing the Signs of Disease: Plague in Arabic Medical Commentaries Between the First and Second Pandemics', in L. Jones and N. Varlık (eds), Death and Disease in the Long Middle Ages (York: York Medieval Press, forthcoming).

${ }^{9}$ Lawrence I. Conrad, 'T $T \bar{a}$ ' $\bar{n}$ and Wabā': Conceptions of Plague and Pestilence in Early Islam', Journal of the Economic and Social History of the Orient, 25 (1982), 268-307, 291 n 84; Fancy, op. cit. (note 8).

${ }^{10}$ The main narrative accounts of the experience of plague in the medieval Islamic world are Dols, The Black Death, op. cit. (note 1); Mohammed Melhaoui, Peste, contagion et martyre. Histoire du fléau en Occident musulman médiéval (Paris: Publisud, 2005); Nükhet Varlık, Plague and Empire in the Early Modern Mediterranean World: The Ottoman Experience, 1347-1600 (Cambridge: Cambridge University Press, 2015).

${ }^{11}$ Reza Pourjavady and Sabine Schmidtke, 'The Quṭb al-Dīn al-Shīrāzī (d. 710/1311) Codex (Ms. Mar'ashī 12868): Studies on Quṭb al-Dīn al-Shīrāzī II', Studia Iranica, 36 (2007), 279-301.

${ }^{12}$ Quṭb al-Dīn al-Shīrāzī, The Mongols in Iran: Quṭb al-Dīn al-Shīrāzī’s Akhbār-i Moghūlān, G. Lane (trans. and ed.) (Abingdon: Routledge, 2018), 54-55/84-86[32,34]; Lane provides both a 'straight translation' (pp. 46-75) and, separately, an annotated one (pp. 76-109), both keyed to the pagination of the Persian edition. Our thanks to Matthew Melvin-Koushki for confirming the readings in the original Persian text.
} 
Mona Hassan, noted in 2017 that there were half a dozen other historical accounts written by contemporaries or by a second generation of chroniclers who record outbreaks of what she describes as 'plague' after the Fall of Baghdad. Hassan's depiction of the scene is vivid:

Emerging from their subterranean places of hiding, these few survivors [of the Mongol siege] would have been confronted with the sight of Baghdad lying in complete ruin and its streets filled with the decaying and disfigured corpses of hundreds of thousands of the city's former residents. The stench was reported to be overwhelming, and combined with the contamination of the city's water by the dead and the descent of flies upon Baghdad, which also contaminated the food supply, these drastic changes were considered to be the cause of the last source of death, the plague, which claimed the lives of almost everyone who had escaped the sword. ${ }^{13}$

In fact, as we will show, none of the historians noted by Hassan specifically documents plague ( $t \bar{a}$ ' $\bar{u} n)$ in Baghdad itself. Several of them do not even record the presence of an epidemic ( $w a b \vec{a})$ in Baghdad (or Iraq). But all of them contribute in some way to information about a lethal, epidemic disease in the regions of Iraq and/or nearby Syria - or even more distant Egypt - in 1258 following the Mongol conquest of Baghdad. Indeed, we find that the list of witnesses can be nearly tripled (see Table 1). Collectively, the thirteenth- and early fourteenth-century chroniclers provide precise dates for when the disease arrived in each region, and identify at least two prominent historical figures who succumbed to it.

Al-Shīrāzî̀'s thirteenth-century testimony of a lethal epidemic outbreak in Baghdad is by far the most detailed. Another contemporary who reported an outbreak in the region from within the Mongol context was Ibn al-'Tbrī (1225-86), better known as Bar Hebraeus. Bar Hebraeus was a physician and a highranking religious figure in the Jacobite (Christian) church. His father had served as a physician under the Mongols, and Bar Hebraeus himself attended to the Mongol ruler as a physician in 1263. He had also lived in Syria, serving as the Metropolitan in Aleppo before becoming the head of the church in Iran under the Mongols. He thus straddled the Mamluk Syrian and Mongol Iranian realms. ${ }^{14}$ At the end of his section on the conquest of Baghdad in his Syriac Chronography, Bar Hebraeus records that, 'at that time, there was a severe famine and deadly epidemic (Ar. wab $\vec{a}$, Syr. mawtāna) in the regions of Baghdad, Assyria, between the two rivers, Syria and Anatolia'. The Syriac term mawtāna was used to refer to plague during the eighth century, but during his time referred more generally to any epidemic disease (shar $u \bar{u} t \bar{a}$ is the specific term for plague). Bar Hebraeus also adds that the epidemic and famine were so severe in Damascus that the price of a young chicken, used for treating the ill, rose substantially. ${ }^{15}$

The remaining fifteen historians and biographers - all of them Syrian and Egyptian authors living under Mamluk rule - wrote in Arabic. None of them cite al-Shīrāzī or Bar Hebraeus's accounts, though that is not surprising not simply because of the language differential but because both were closely allied to the rival Ilkhanate court. We have split these authors into four groups. The first generation is made up of scholars who were contemporaries and relied on direct experience and eye-witness testimony of the events of 1258. The second generation relied on the earlier generation and testimonies of other contemporary witnesses; all died before or within the first 2 years of the 1348/9 plague outbreak. The third generation of scholars were predominantly students or younger contemporaries of the second generation but, crucially, experienced over a decade or more of the Black Death outbreaks. And, finally, there are historians who died in the fifteenth century (even if, in one case, their work was produced towards the end of the fourteenth century). This last generation of historians, especially al-Maqrīzī, has dominated the narratives of modern academic scholarship on the Second Pandemic in Islamic societies.

\footnotetext{
${ }^{13}$ Hassan, op. cit. (note 6), 47. In her notes (p. 279 n. 94), she lists six of the sixteen sources included in our study (see Table 1).

${ }^{14} \mathrm{P}$. Bearman et al. (eds) Encyclopaedia of Islam, Second Edition (Leiden: Brill, 1960-2007). Henceforth, EI2, s.v. 'Ibn al-'Ibrì (J. B. Segal).

${ }^{15}$ Ibn al-'Ibrī, Ta’rīkh al-zamān, A. I. Armala (trans.) (Beirut: Dār al-Mashriq, 1991), 309; P. Bedjan (ed.), Gregorii Barhebroi Chronicon Syriacum e codd. mss. emendatum ac punctis vocalibus adnotationibusque locupletatum (Paris: Maisonneuve, 1890), 506. Our thanks to Taro Mimura for identifying the Syriac term.
} 
Table 1. Testimonies of deadly disease after the Mongol siege and conquest of Baghdad (1258) If the author states that the disease prevailed over Syria and even reached Damascus, then both are included in the list. However, if the author states that the disease prevailed over Kufa and Basra, then only those cities are mentioned and not Iraq as a region. Sources marked by an asterisk are those cited by Hassan, op. cit. (note 6).

\begin{tabular}{|c|c|c|c|c|c|c|}
\hline Generation & Author & $\begin{array}{l}\text { Death } \\
\text { date }\end{array}$ & Author's place(s) & Term(s) used & Region(s) affected & $\begin{array}{l}\text { Individuals identified as } \\
\text { dying of disease }\end{array}$ \\
\hline \multirow[t]{4}{*}{ First generation } & Abū Shāma & 1268 & Damascus & Wabā' & Damascus and surrounding regions & Unknown \\
\hline & Ibn Khallikān & 1282 & $\begin{array}{l}\text { Cairo } \\
\text { Damascus }\end{array}$ & Maraḍ ‘aẓīm & Egypt, Cairo & Bahā’ al-Dīn Zuhayr \\
\hline & Bar Hebraeus* & 1286 & $\begin{array}{l}\text { Malatya } \\
\text { Aleppo, Mosul } \\
\text { Baghdad } \\
\text { Maragha }\end{array}$ & Waba’ & $\begin{array}{l}\text { Baghdad, Assur, Iraq between } \\
\text { the two rivers; } \\
\text { Syria, Damascus; Anatolia }\end{array}$ & None \\
\hline & Ibn Wāṣil & 1298 & $\begin{array}{l}\text { Aleppo } \\
\text { Damascus } \\
\text { Hama, Cairo } \\
\text { Sicily }\end{array}$ & $\begin{array}{l}\text { Waba’ } \\
\text { Ṭăūūn }\end{array}$ & Syria; Egypt, Cairo & $\begin{array}{l}\text { al-Nāșir Dāwūd (țāūn); } \\
\text { Bahā’ al-Dīn Zuhayr (wabā) }\end{array}$ \\
\hline \multirow[t]{6}{*}{$\begin{array}{l}\text { Second } \\
\text { generation }\end{array}$} & Anonymous* & c. 1320 & Baghdad (?) & Wabā' & Baghdad & $\begin{array}{l}\text { Badr al-Dīn al-Lu’lu' } \\
\text { (unnamed disease) }\end{array}$ \\
\hline & al-Yūnīn̄̄ & 1326 & $\begin{array}{l}\text { Damascus Ba'labakk } \\
\text { Egypt }\end{array}$ & $\begin{array}{l}\text { Wabā’’ } \\
\text { Ṭăưun }\end{array}$ & $\begin{array}{l}\text { Syria, Buwayḍa } \vec{a} \text {, Damascus (waba only); } \\
\text { Egypt, Cairo (waba only). }\end{array}$ & $\begin{array}{l}\text { al-Nāșir Dāwūd (țāūn); } \\
\text { Bahā’ al-Dīn Zuhayr (wabā) }\end{array}$ \\
\hline & Abū al-Fidā’’ & 1331 & $\begin{array}{l}\text { Damascus } \\
\text { Hama }\end{array}$ & $\begin{array}{l}\text { Wabā' } \\
\text { Ṭăūūn }\end{array}$ & $\begin{array}{l}\text { Wabā': Syria, Damascus; Cairo } \\
\text { Ṭăữn: Syria, Buwaydāā' }\end{array}$ & $\begin{array}{l}\text { al-Nāșir Dāwūd (țāūun); } \\
\text { Bahā’ al-Dīn Zuhayr (wabā) }\end{array}$ \\
\hline & al-Dhahabī & 1348 & $\begin{array}{l}\text { Damascus } \\
\text { Cairo }\end{array}$ & $\begin{array}{l}\text { Wabā’’ } \\
\text { Ṭăưun }\end{array}$ & $\begin{array}{l}\text { Wabāas: Baghdad; Syria, Damascus, Aleppo; } \\
\text { Cairo } \\
\text { Ṭăđūn: Syria, Buwayḍāa }\end{array}$ & $\begin{array}{l}\text { al-Nāșir Dāwūd (țāūūn); } \\
\text { Bahāà al-Dīn Zuhayr (wabāa) }\end{array}$ \\
\hline & al-'Umarī & 1349 & $\begin{array}{l}\text { Damascus } \\
\text { Cairo }\end{array}$ & $\begin{array}{l}\text { Wabā’ } \\
\text { Ṭăūūn }\end{array}$ & $\begin{array}{l}\text { Wabāā: Syria, Damascus } \\
\text { Ṭăūun: Syria, Buwayḍāa’ }\end{array}$ & al-Nāșir Dāwūd (țāūn) \\
\hline & Ibn al-Wardī & 1349 & $\begin{array}{l}\text { Hama } \\
\text { Damascus Aleppo }\end{array}$ & $\begin{array}{l}\text { Wabā’ } \\
\text { Ṭăūūn }\end{array}$ & $\begin{array}{l}\text { Wabāà: Syria, Damascus; Cairo } \\
\text { Ṭăữn: Buwayḍā’ }\end{array}$ & $\begin{array}{l}\text { al-Nāșir Dāwūd (țāūnn); } \\
\text { Bahā’ al-Dīn Zuhayr (wabā) }\end{array}$ \\
\hline
\end{tabular}


Table 1. Continued

\begin{tabular}{|c|c|c|c|c|c|c|}
\hline Generation & Author & $\begin{array}{l}\text { Death } \\
\text { date }\end{array}$ & Author's place(s) & Term(s) used & Region(s) affected & $\begin{array}{l}\text { Individuals identified as } \\
\text { dying of disease }\end{array}$ \\
\hline \multirow[t]{3}{*}{ Third generation } & $\begin{array}{l}\text { Ibn Shākir } \\
\text { al-Kutubīi }\end{array}$ & 1363 & Damascus & Wabā' Tăūūn & $\begin{array}{l}\text { Wabāa': Baghdad; Syria; Egypt, Cairo. } \\
\text { Ṭāūūn: Syria, Buwaydāā; Egypt. }\end{array}$ & $\begin{array}{l}\text { al-Nāșir Dāwūd (țāūūn); } \\
\text { Bahā’ al-Dīn Zuhayr (wabā) }\end{array}$ \\
\hline & al-Șafadī & 1363 & $\begin{array}{l}\text { Safad, Cairo } \\
\text { Damascus }\end{array}$ & $\begin{array}{l}\text { Wabāa } \\
\text { Ṭăūūn }\end{array}$ & $\begin{array}{l}\text { Wabā’: Cairo } \\
\text { Ṭāūūn: Syria, Buwayḍāa’ }\end{array}$ & $\begin{array}{l}\text { al-Nāșir Dāwūd (țāūūn); } \\
\text { Bahā’ al-Dīn Zuhayr (wabā) }\end{array}$ \\
\hline & Ibn Kathīr* & 1373 & Damascus & $\begin{array}{l}\text { Wabā’ } \\
\text { Ṭăūun }\end{array}$ & $\begin{array}{l}\text { Wabā': Baghdad, Syria } \\
\text { Ṭăüūn: Syria }\end{array}$ & None \\
\hline \multirow{3}{*}{$\begin{array}{l}\text { Fourth } \\
\text { generation }\end{array}$} & al-Malik al-Ashraf* & 1401 & Yemen & Wabā & Syria, Aleppo; Damascus & None \\
\hline & al-Maqrīzī & 1442 & $\begin{array}{l}\text { Cairo } \\
\text { Damascus }\end{array}$ & Wabā' & Syria, Aleppo; Damascus & None \\
\hline & Ibn Taghrībirdī & 1470 & Cairo & Wabāa & Damascus & None \\
\hline
\end{tabular}


As Table 1 shows, the first generation of contemporaries listed disease outbreaks only in regions where they were living or had previously lived. And, with one notable exception, they did not explicitly and unambiguously classify the lethal, disease outbreak as plague (țāūn $)$. For example, Abū Shāma (1203-68), a Damascene historian, ${ }^{16}$ only reports a lethal disease outbreak in Damascus and its environs. In the midst of listing the scholars who died in the year 1258, Abū Shāma pauses when he gets to the month of Jumāda I/May and notes, 'And there was a lot of $w a b \vec{a}$ [epidemic disease] in the time of Spring, which was one of the stranger things to happen. People fell ill more than normal and many died' ${ }^{17} \mathrm{He}$ then documents over a dozen deaths of scholars and notables (mostly in and around Damascus) during the spring months, including the death of the former Ayyubid ruler of Damascus and Karak, al-Malik al-Nāṣir Dāwūd on 26 Jumāda I/31 May. However, since Abū Shāma does not explicitly say that the Ayyubid ruler or any of the other Syrian notables died from a disease, for the purposes of our study, we classified all of these deaths as 'cause unknown'.

Abū Shāma's contemporary, Ibn Khallikān (1211-82), had also resided in many cities across Syria and Iraq. Yet he only records the outbreak of a great disease (marad 'azim) for Cairo and northern Egypt, where he was residing since 1256 as the deputy to the chief judge of Egypt. ${ }^{18}$ His report on the outbreak is found within his biographical dictionary entry on his friend, Bahā al-Dīn Zuhayr, who died in Cairo on 4 Dhu al-Qa'da/3 November from this disease. Bahā’ al-Dīn was a close confidant of the Ayyubid prince and ruler of Damascus, and later Sultan of Egypt, al-Șāih Ayyūb (r. 1240-9). He was the 'finest poet of his day, and perhaps the finest for many generations'. ${ }^{19}$ Ibn Khallikān states this great disease, 'from which almost no one was safe', started in northern Egypt on 24 October. Bahä al-Dīn was one of the unfortunate ones who was struck by this suffering (alam); he died a few days after contracting the disease. Ibn Khallikān then adds, 'I could not make it for [Bahā' al-Dīn's funeral] prayer as I was engaged myself with the disease. When I had recovered from the disease, I proceeded to his grave for visitation and read a part of the Qur'ān for him'. ${ }^{20}$ Despite contracting the disease himself, the only symptom Ibn Khallikān records is that it was lethal and killed people quickly.

Unlike other contemporary witnesses, Ibn Wāṣil (1208-98) not only describes specific symptoms, but also uses the term $t_{\bar{a}} \bar{u} \bar{u} n$ to refer to the lethal disease outbreak in both Syria and Egypt. Ibn Wāșil was a Syrian historian, judge and belles-lettrist from Hama who spent much of his life in various parts of the region. He was attached to the court of the Ayyubid ruler, the aforementioned al-Nāșir Dawūd, in Karak, where he also studied under al-Nāșir Dawūd's physician-philosopher, Shams al-Dīn Khusrawshāhī (d. 1254). Between 1243 and 1265, Ibn Wāșil resided in Cairo serving various Ayyubid and Mamluk rulers, including Sultan Baybars al-Bunduqdārī (r. 1260-77). ${ }^{21}$ In his chronicle, Ibn Wāṣil provides a personal account of the epidemic in Cairo and lower Egypt, and records a key eyewitness account on the outbreak in Syria, during which his former patron died. ${ }^{22}$ He is also the only contemporary Ayyubid/ Mamluk historian who connects the disease outbreak to the mass killing in Baghdad.

Ibn Wāṣil begins his long account of al-Nāṣir Dāwūd's death by stating, 'In this year [i.e. 1258], plague $\left(t \bar{a}^{c} \bar{u} n\right)$ struck across Syria, the regions of Egypt, and the like on account of that [i.e. the killing in Baghdad]'. He explains that the plague occurred because the slaughter in Baghdad corrupted the temperament of the air. ${ }^{23} \mathrm{He}$ describes his own observations of the outbreak in Egypt, recording some of its symptoms, lethality and speed of movement:

\footnotetext{
${ }^{16}$ EI2, s.v. 'Abū Shāma' (Hilmy Ahmad); R. Stephen Humphreys, From Saladin to the Mongols: The Ayyubids of Damascus, 1193-1260 (Albany: SUNY Press, 1977), 398.

${ }^{17}$ Abū Shāma, Tarājim rijāl al-qarnayn al-ma'rūfbi-l-Dhayl 'alā al-rawdatayn, I. Shams al-Din (ed.) (Lebanon: Dār al-Kutub al-'Ilmiyya, 2002), V: 305.

${ }^{18}$ EI2, s.v. 'Ibn Khallikān' (J. W. Fück).

${ }^{19}$ Humphreys, op. cit. (note 16), 251-2.

${ }^{20}$ Ibn Khallikān, Wafāyāt al-a yyān wa-anbā’ abnā̄ al-zamān, I. 'Abbas (ed.) (Beirut: Dār Ṣādir, 1978), II: 338.

${ }^{21} E I 2$, s.v. 'Ibn Wāṣil' (G. D. el-Shayyal).

${ }^{22}$ Humphreys, op. cit. (note 16), 396, 399.

${ }^{23}$ Ibn Wāșil, Mufarrij al-kurūb fì akhbār ban̄ Ayyūb, Bibliothèque Nationale de France, Paris, MS BNF 1073, https:// gallica.bnf.fr/ark:/12148/btv1b110010632, fols. 130a-b.
} 
A fever and cough occurred in Bilbeis [on the eastern edge of the southern Nile delta] such that not one person was spared from it, yet there was none of that in Cairo. Then after a day or two, something similar happened in Cairo. I was stationed in Giza at that time. I rode to Cairo and found that this condition was spreading across the people of Cairo, except a few.

He states that he contracted the disease when he returned to Giza. The disease moved from one region to the next every 3 days until all Egyptian provinces had succumbed to it over time. Later, he adds that the famous poet Bahā al-Dīn died in Egypt from this outbreak (here calling it a $w a b \vec{a}) .{ }^{24}$

In recording the death of al-Nāṣir al-Dāwūd, Ibn Wāșil relies upon 'Abd Allāh ibn Faḍl, an attaché of his former patron. Ibn Fadl stated that when the severe epidemic (wabas) and plague ( $\left.t \bar{a}^{-} \bar{u} n\right)$ caused by the Mongol seizure of Baghdad hit Syria, the people resented it. At that time, al-Nāṣir al-Dāwūd recited to them the incident of the plague of 'Amwās at the time of the caliph 'Umar ibn al-Khațāb (639), an outbreak that had been a fixture of hadith commentary about plague since at least the ninth century. He reminded them of the fact that the plague is a mercy from God for Muslims and not akin to the plagues sent as punishment to the Children of Israel. Ibn Fadl then recounted that a day or two after the Ayyubid ruler's exhorting his camp in Buwaydāa , a village east of Damascus, the ruler himself was afflicted with plague (Ibn Wāṣil uses the very specific term for plague-stricken, maț ùn ). Al-Nāṣir Dāwūd was said to be in such excruciating pain on his left side that he could not lie down. Ibn Fadl also recorded two dreams the ruler had prior to his death, including one in which he saw his left side speak to his right. Ibn Wāșil states that so many people died of this $w a b \bar{a}$ and $t \bar{a} \bar{u} n$ in Syria that it became impossible to find washers of dead bodies. The prices of certain items rose exponentially too, such that chickens were sold for over 10 dirhams in Aleppo, and a raț (just oveer a pound) of tamarind sold for 60 dirhams.

While only Ibn Wāṣil was willing to call it plague $\left(t \bar{a}^{t} \bar{u} n\right)$, and only two historians acknowledged any outbreak in Egypt, taken together all of the first generation reports agree on the severity of the outbreak(s) and its timing. The situation is reversed amongst the second generation, that is to say all but one of them explicitly refer to an outbreak of plague ( $\left.t \bar{a}^{-} \bar{u} n\right)$ in Syria. The works we examined from the historians of this generation also all specify at least one major figure who died of this lethal epidemic in the aftermath of the Fall of Baghdad.

The anonymous author of Hawädith al-jämia is the only one who does not mention plague in his account. This text, which records local events in the region of Baghdad up to around 1301, has been attributed to Ibn Fuwatī (1244-1323) by the editor of this work, but scholars now concur that it was most likely composed by a contemporary who had intimate knowledge about the events in Baghdad. In fact, Hassan's vivid portrayal of the incidence of plague after the Fall of Baghdad seems to largely paraphrase the Hawädith account, the only difference being that Hassan refers to the disease as plague while the Hawàdith text uses the more generic 'epidemic' (wabä):

It is said that there were more than 800,000 dead in Baghdad, not including the children thrown in the mud, those who perished in the canals, wells, and basements, and those who died of hunger and fear. Those that survived the killing were struck by an epidemic [wab $\left.\vec{a}^{3}\right]$ from breathing the odor of corpses and drinking contaminated water. The inhabitants frequently smelled onions because of the strong smell. The number of flies increased, filling the air; they would fall on food and spoil it. The inhabitants of Hilla, Küfa, and Sīb used to bring food to Baghdad. These people benefitted from selling food for the [exorbitant] price of gemmed books, inlayed brassware or other valuable objects. Many of them enriched themselves this way. ${ }^{26}$

\footnotetext{
${ }^{24}$ Ibid., fols. $130 \mathrm{~b}, 137 \mathrm{~b}$.

${ }^{25}$ Ibid., fols. 130b-131a, 141a.

${ }^{26}$ Ibn Fuwațī, al-Hawādith al-jāmía wa-l-tajārib al-nāfía fì al-mìa al-sābía, M. al-Najm (ed.) (Beirut: Dār al-Kutub al-'Ilmiyya, 2003), 237. Translated in Hend Gilli-Elewy, 'Al-Hawādit al-ğāmi'a: A Contemporary Account of the Mongol Conquest of Baghdad, 656/1258', Arabica, 58 (2011), 353-71, 368.
} 
Even though this account confirms the earlier recording of a famine and epidemic in Baghdad by Bar Hebraeus, it is substantially more detailed suggesting that the Hawädith author may have had access to other eyewitness accounts, or he was more inclined towards connecting the disease event to corrupted air, as Ibn Wāsil had done, or both.

The two towering figures of early Mamluk historiography, al-Yūnīnī (1242-1326) and al-Dhahabī (1274-1348), also link the disease outbreaks of 1258 directly to the corruption caused by the killings in Baghdad. ${ }^{27}$ They rely heavily on Ibn Wāsil's account and claim that a plague (țācun $)$ struck Damascus and the rest of Syria. ${ }^{28}$ Al-Yūnīnī follows Ibn Wāșil in claiming that a plague broke out in Egypt too, ${ }^{29}$ whereas al-Dhahabī does not do so. Al-Dhahabī adds new material on the effect of the lethal epidemic in Aleppo, stating that ' 1100 funerals were carried out of Aleppo every day'. He records the scarcity of both physicians and medicines in Damascus, where the disease was indescribable. ${ }^{30}$ Since al-Dhahabi was not alive at the time, he is most likely relying on the testimony of his teacher Jamāl al-Dīn who was an eyewitness to these events. ${ }^{31} \mathrm{Al}-\mathrm{Dh}$ hahabī (whose treatise on prophetic medicine connects hadìth on plague with a revised medical understanding of the disease) also seems to be the first historian to combine the Mongol and Mamluk traditions of regional outbreaks (Baghdad, Syria and Egypt) together, since, unlike Ibn Wāṣil, he links the corruption resulting from the killing in Baghdad to an epidemic (wabā) outbreak amongst the survivors in the city itself. ${ }^{32}$

The three other historians from this generation do not explicitly connect the corruption spreading from Baghdad to the disease outbreak in Syria, but they do refer to the disease as plague. Abū al-Fidā (1273-1331) was a Syrian Ayyubid prince and historian who spent most of his life in Hama. ${ }^{33}$ The other two historians, al-'Umarī (1301-49), head of chancery in Cairo and Damascus, and Ibn al-Wardī (1290/1292-1349), a Syrian belles-lettrist and historian most famous for his plague treatise that was composed during the plague outbreak of $1348 / 9$, both rely heavily on Abū al-Fidā's account. ${ }^{34}$ Ibn al-Wardī, in fact, described the outbreaks in Syria and Egypt within his abridgment and continuation of Abū al-Fidā"s universal history. They all record the death of al-Nāṣir Dāwūd from plague, and highlight the scarcity of corpse washers due to the heavy mortality in Damascus. ${ }^{35}$ Abū al-Fidā' and Ibn al-Wardī also record that Bahā' al-Dīn died of an epidemic that was prevalent in Egypt at the time. ${ }^{36} \mathrm{Al}-$ 'Umarī, however, neither records the poet's death nor does he record a disease outbreak in Egypt.

We thus see an emergence of a trend that the Egyptian epidemic is reported only in the context of the biographical notice of Bahā' al-Dīn, whereas the Syrian outbreak is reported more widely even outside of al-Nāṣir Dāwūd's biography. The only exception is al-Yūnīnī who, like Ibn Wāșil, continued to report on the epidemic in Egypt outside the confines of Bahā' al-Dīn's entry. The Hawädith's recording of the death of the ruler of Mosul, Badr al-Dīn Lu'lu', due to a disease is not connected to any $w a b \bar{a}^{\prime}$ or țā'īn in that region by the Syro-Egyptian historians. ${ }^{37}$ Finally, only al-Dhahabī and al-Yūnīnī copy Ibn Wāsil's

\footnotetext{
${ }^{27}$ For more on these scholars, see EI2, s.v. 'al-Yūnīnì' (J. Sublet) and s.v. 'al-Dhahabî̀ (M. Ben Cheneb [J. D. Somogyi]).

${ }^{28}$ al-Yunīnī, Dhayl Mir'āt al-zamān (Hyderabad: Osmania Oriental Publications Bureau, 1954), I: 91; al-Dhahabī, Ta'rīkh al-Islām wa-wafāyāt al-mashāhīr wa-l-a lām, U. A. S. Tadmuri (ed.) (Beirut: Dār al-Kutub al-'Arabī, 1990), XLVIII: 42.

${ }^{29}$ al-Yūnīnī, ibid., I: 174.

${ }^{30} \mathrm{Al}-\mathrm{Dh} h \mathrm{hab} \mathrm{i}$ records over thirty-three deaths of scholars and notables across Syria between March and November 1258, the bulk of which took place between March and June. Except for al-Nāșir Dāwūd, he does not explicitly state that they died of a disease, but some of them were only in their thirties. For Cairo, he records just over a dozen deaths between the months of October and December, but $w a b \vec{a}$ is listed as the cause of death only for Bahā' al-Dīn Zuhayr.

${ }^{31}$ Hassan, op. cit. (note 6), 47.

${ }^{32}$ al-Dhahabī, op. cit. (note 28), XLVIII: 39.

${ }^{33} E I 2$, s.v. 'Abū l-Fidā”' (H. A. R. Gibb).

${ }^{34} E I 2$, s.v. 'Ibn Faḍl Allāh al-'Umarì' (K. S. Salibi) and s.v. 'Ibn al-Wardī' (M. Ben Cheneb).

${ }^{35}$ Abu al-Fidā', Kitāb al-Mukhtașar fĭ akhbār al-bashar (Cairo: al-Maṭba'a al-Husayniyya, 1907), III: 195, 197; al-'Umarī, Masālik al-abșār fì mamālik al-amșār, K. S. al-Jaburi (ed.) (Beirut: Dār al-Kutub al-'Ilmiyya, 1971), XXVII: 245-7; Ibn al-Wardī, Ta'rīkh Ibn al-Wardī (Beirut: Dār al-Kutub al-'Ilmiyya, 1996), II: 192-3.

${ }^{36}$ Abū al-Fidā', ibid., III: 197; Ibn al-Wardī, ibid., II: 194.

${ }^{37}$ Ibn Fuwațī, op. cit. (note 26), 242. The author recognises that others claim that the ruler of Mosul died the following year in 1259, which is exactly the year in which al-Dhahabī records his death; op. cit. (note 28), XLVIII: 322-4.
} 
detailed description of al-Nāṣir Dāwūd's experience with plague, including the vivid accounts of his dreams prior to his death. ${ }^{38}$

Amongst the third generation of historians, the Black Death generation, we see a reduction and greater caution in using the term $t \bar{a} \bar{u} n$, and a much more restricted use of $w a b \bar{a}$ for Egypt, a trend that will result in the complete disappearance of any memory of plague in Syria, or a lethal epidemic in Egypt by the fifteenth century. All three Syrian, Mamluk historians we have examined from the third generation - Ibn Shākir al-Kutubī (1287-1363), al-Ṣafadī (1297-1363) and Ibn Kathīr (1301-1373) knew one another personally, and shared some teachers and professional connections (e.g. all were connected to al-Dhahabī and his circle in Damascus); hence, it is not surprising to see many overlaps in their works. Nevertheless, Ibn Shākir, who was involved in the book trade, is known to have sought out sources that had been ignored by his contemporaries, which accounts for noticeable differences between his accounts of 1258 and those of his peers (Ibn Kathïr was a highly esteemed religious scholar of his time, while al-Safadī was the son of a Mamluk soldier and held official government positions in addition to being a religious scholar). ${ }^{39}$

All three of them connect the plague outbreak in Syria to the corruption caused by the killings in Baghdad. ${ }^{40}$ Ibn Shākir and Ibn Kathīr even record a $w a b \bar{a}$ in Baghdad itself. Ibn Shākir, writing from Damascus, provides the most vivid description of the corruption that caused the epidemic in Baghdad. His description seems to be based on the Hawädith (or a common source) since he mentions details not found in other Syro-Egyptian works, such as flies filling the air and spoiling the food by dropping in it. ${ }^{41}$ Ibn Kathīr, basing himself on al-Dhahabī, reports the widespread killing which led to corpses being piled up on the roads. The corruption from these corpses not only caused a $w a b \vec{a}$ to occur in Baghdad, but this $w a b \vec{a}$ travelled in the air to Syria and became a taçün (see section III). The people of Syria were thus subjected to 'high prices, epidemic, destruction, piercing and plague, all at once!' ${ }^{42}$ On Egypt, Ibn Shākir continues the tradition of Ibn Wāșil and al-Yūnīnī by reporting on a widespread epidemic in that region caused by the corruption in Baghdad which also killed the poet, Bahā' al-Dīn. ${ }^{43}$ Neither al-Ṣafadī nor Ibn Kathīr make such broad claims. Al-Ṣafadī merely states that Bahä al-Dīn fell ill and died during the time of the epidemic, whereas Ibn Kathīr does not even refer to a disease in his entry on the poet. ${ }^{44}$ Similarly, relying on al-Yūnīnī, Ibn Shākir records not only the Ayyubid ruler's death from plague, but even his experience of pain and his dreams. ${ }^{45} \mathrm{Al}$-Șafadī, on the other hand, merely states that al-Nāṣir Dāwūd died from the plague that broke out in Syria, whereas Ibn Kathīr not only leaves out the cause of the ruler's death, but even claims that he died the year prior in $1257 !^{46}$

Moving into the late fourteenth century and fifteenth century, when each of our three historians would have witnessed multiple waves of plague during their lifetimes, we find that the paths of erasure already discernible within the works of the Black Death generation became fixed. No fourth-generation historian we examined referred to any disease outbreak in Egypt (or Iraq) after the fall of Baghdad. None of them even use the unambiguous term $t \bar{a}^{-} \bar{u} n$ to identify the epidemic outbreak in Syria as plague even though they were intimately familiar with the work of al-Dhahabī (and others). Al-Malik al-Ashraf (1360-1401), a historian and member of the Rasulid ruling family in Yemen, only uses the term $w a b \bar{a}^{2}$ while describing the disease that ravaged Syria, paraphrasing (without attribution) al-Dhahabî's account that the epidemic resulted in 1100 deaths a day in Aleppo alone, a scarcity in physicians and an increase

\footnotetext{
${ }^{38}$ Al-Yūnīnī, op. cit. (note 28), I: 174-6; and al-Dhahabī, op. cit. (note 28), XLVIII: 248-9.

${ }^{39}$ EI2, s.v. 'al-Kutubì' (F. Rosenthal), s.v. 'Ibn Kathīr' (H. Laoust), and s.v. 'al-Ṣafadī' (F. Rosenthal).

${ }^{40}$ Ibn Shākir al-Kutubī, 'Uyūn al-Tawārīkh, U. K. F. al-Nasir and N. A. M. Dawud (eds) (Baghdad: Dār al-Rashīd li-l-Nashr, 1980), XX: 135, 142, 169-70, 181; al-Ṣafadī, Kitāb al-Wafì bi-l-wafāyāt, A. al-Arnaut and T. Mustafa (eds) (Beirut: Dār Iḥyā’ li-l-Turāth al-'Arabī, 2000), XIII: 308; Ibn Kathīr, al-Bidāya wa-l-nihāya (Beirut: Maktabat al-Ma'ārif, 1990), XIII: 203.

${ }^{41}$ Ibn Shākir, ibid., XX: 135.

${ }^{42}$ Ibn Kathīr, op. cit. (note 40), XIII: 203.

${ }^{43}$ Ibn Shākir, op. cit. (note 40), XX: 181.

${ }^{44} \mathrm{Al}-\mathrm{S}$ afadī, op. cit. (note 40), XIV: 159.

${ }^{45}$ Ibn Shākir, op. cit. (note 40), XX: 169-170.

${ }^{46}$ Al-Ṣafadī, op. cit. (note 40), XIII: 308; Ibn Kathīr, op. cit. (note 40), XIII: 198.
} 
in the prices of medical ingredients. ${ }^{47}$ Al-Maqrīzī (1364-1442), the celebrated historian, similarly records the $w a b \bar{a}$ in Syria that killed people in Damascus and Aleppo. ${ }^{48}$ Ibn Taghrībirdī, who was also a historian and son of a Mamluk soldier, records the $w a b \bar{a}$ that broke out in Damascus and other regions in one pithy sentence. ${ }^{49}$ Most importantly, none of them connect the epidemic outbreak in Syria to corruption spreading from Baghdad. Nor does any of them record the deaths by $t \bar{a} \bar{u} n$ and $w a b \bar{a}$ of al-Nāșir Dāwūd and Bahāà al-Dīn, respectively. The downgrading of the 1258 plague outbreak in Syria to a simple $w a b \vec{a}^{3}$, and the erasure of a widespread, lethal epidemic across Iraq, Syria and Egypt, was thus solidified in the historiographic canon.

\section{Plague in the medical and Hadith commentaries after 1258}

While the chronicles may have treated the outbreaks of 1258 as phenomena confined to a single year, there were others for whom plague, as a specific disease, carried more comparative interest. In a forthcoming chapter, Fancy shows that there is a recognisable shift in how plague was discussed in the medical commentaries produced after the Fall of Baghdad. ${ }^{50}$ This shift is prominent in three specific ways. First, the new commentaries highlight symptoms that were barely (if at all) addressed in the earlier literature, such as delirium, bad odour of the buboes and chills. Second, these medical works provide a much more concise clinical description of plague symptoms than what is found in earlier works, including Ibn Sīnās (d. 1037, lat. Avicenna) Canon of Medicine. Finally, although the three primary sites for the eruption of buboes (groin, behind the ears and the armpits) were known to Arabic medical writers since the eighth century, we see an interesting shift in the thirteenth century wherein the Syrian and Iranian medical authors who discussed plague after the Fall of Baghdad all claimed that a plague bubo erupts mostly in the armpits.

For example, Muwaffaq al-Dīn al-Sāmirī (d. 1282), a Damascene physician, while commenting (circa 1242-69) ${ }^{51}$ on Avicenna's brief discussion in the Canon on the different types of hot swellings, makes the following additions (underlined text) to Avicenna's text: 'When an abscess occurs in the three maghäbin ${ }^{52}$ - in the groin, behind the ears, and especially under the armpits, [and the abscess] is made of corrupt blood whose harm reaches the heart, it is called a plague bubo'. ${ }^{33}$ The same highlighting of buboes under the armpits is found in the work of his student, Ibn al-Quff (d. 1286), who also studied under Khusrawshāhī, al-Nāṣir Dāwūd's physician and Ibn Wāṣil's teacher (Figure 1). Even though Ibn al-Quff is not mentioned in al-Nāșir Dāwūd's entourage when the latter died, one wonders whether his very precise (and concise) description of plague symptoms was based on reports of the plague outbreak in Buwayḍā'. In his Commentary on the Aphorisms, a work completed after 1258, Ibn al-Quff, like al-Sāmirī, states that the word $t \bar{a} \bar{u} n$ in his time means 'a cold or hot [swelling] that occurs under the armpits'. He then states that the symptoms of plague are: 'black odour, black colour around the swelling, fainting on some occasions and cold sweat. All this (happens) when the vapours reach the heart from it'. ${ }^{4}$

\footnotetext{
${ }^{47}$ al-Malik al-Ashraf, al-'Asjad al-masbūk wa-l-jawhar al-mahkūk fï țabaqāt al-khulafä̀ wa-l-mulūk, S. 'Abd al-Mun'im (ed.) (Beirut: Dār al-Turāth al-Islāmī, 1975), I: 645.

${ }^{48}$ al-Maqrīzī, Kitāb al-Sulūk li-márifat duwal al-mulūk, M. M. Ziyadah (ed.) (Cairo: Dar al-Kutub al-Mișriyya, 1936), I.2: 410.

${ }^{49}$ Ibn Taghrībirdī, al-Nujūm al-zāhira fĭ mulūk mișr wa-l-qāhira (Cairo: Wizārat al-Thiqāfa Miṣr, n.d.) VII: 60.

${ }^{50}$ Fancy, op. cit. (note 8).

${ }^{51}$ E. Savage-Smith, S. Swain and G. van Gelder (eds), A Literary History of Medicine (Leiden: Brill, 2020), 15.59.

${ }^{52} \mathrm{Ibn}$ Sīnā uses the term maghäbin to refer to the armpits while al-Sāmirī seems to be using it to refer to areas of soft, white, glandular flesh.

${ }^{53}$ Muwaffaq al-Dīn al-Sāmirī, Sharh Kulliyyāt al-Qānūn, Oxford, Bodleian Library, MS Marsh 464, 285.

${ }^{54} \mathrm{Ibn}$ al-Quff, Commentary on the Hippocratic Aphorisms, Book Four, P. E. Pormann et al. (eds) (Manchester: Wiley VCH, 2017), 85-6, http://doi.org/10.3927/52132103, last accessed 11 September 2019; Fancy, op. cit. (note 8). These revised understandings of plague are picked up by al-Shīrāzī, who owned and used Ibn al-Quff and al-Sāmirī's works in his Canon commentary, leading him to conclude that physicians in his time refer to swellings under the armpits specifically as plague buboes.
} 


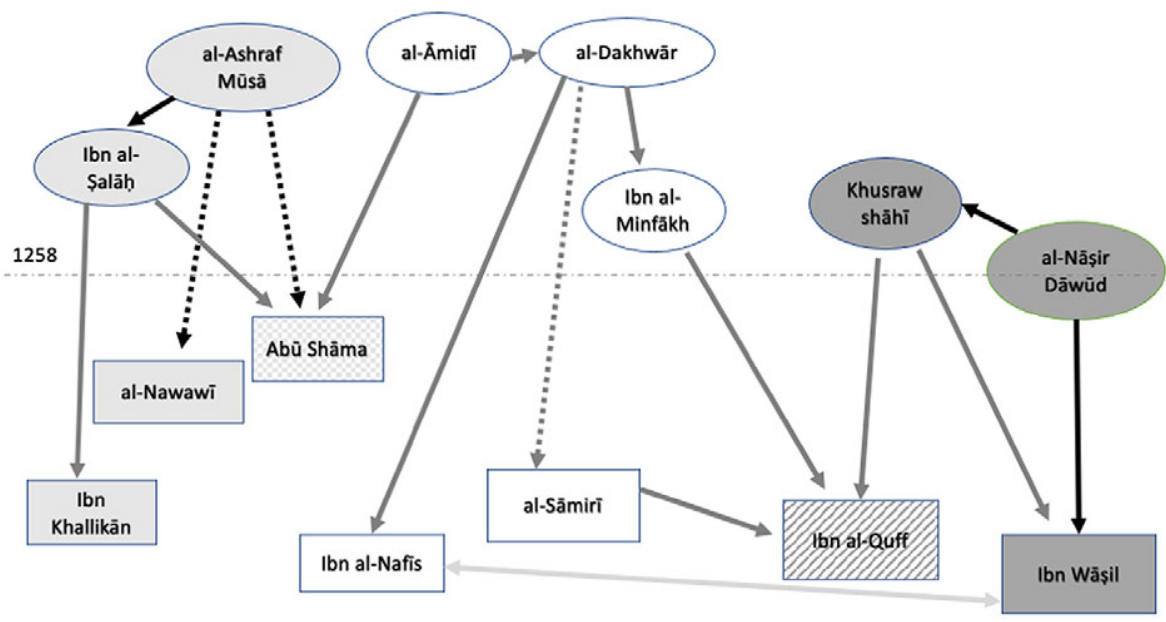

Figure 1. Network analysis of authors who trained in Damascus in the thirteenth century. Rectangles indicate authors who reported on disease outbreaks in 1258 or modified their understanding of plague based on those outbreaks. Ovals indicate teachers or patrons. Grey arrows indicate a teaching relationship. Black arrows indicate a patronage relationship. Dashed arrows indicate an indirect relationship. Different shades have been used to indicate the patronage/teaching circles to which each scholar belonged.

That new medical understandings of plague's symptoms were of interest to more than practicing physicians is evident in the work of the famous Damascene religious scholar, al-Nawawī (d. 1277). Al-Nawawi provided perhaps the most succinct and precise description of plague symptoms in the midst of his commentary on Muslim ibn al-Hajjajj's (d. 875) canonical collection of sound Prophetic traditions (sing. hadith). The commentary was completed after the Fall of Baghdad, while he was residing in Damascus. In its introduction, while ascertaining the dates of a transmitter who was reported to have lived through a specific plague outbreak in the seventh century, al-Nawawi describes plague thus: 'As for the plague, it is a well-known kind of pestilence involving pustules [bathr] and extremely painful swellings [waram], the eruption of which is accompanied by a fiery inflammation. The surrounding area blackens, and darkens or reddens into a dingy purple; and with this there also occurs palpitation of the heart and nausea. ${ }^{55}$ Later, when commenting on the famous Prophetic hadith that suggests not approaching a region that has the plague or fleeing from it if one is there, al-Nawawi describes the symptoms of plague again. Here, he adds the following sentence to his earlier description, 'Plague is [a disease in which] sores (qurūh) emerge on the body (jasad). They may appear in elbows, armpits, hands or fingers, or the entire body. A swelling (waram) and extreme pain accompanies them'. ${ }^{56}$ While earlier in the introduction, he had lumped up swellings and pustules, al-Nawawī now distinguishes between sores/ulcers and a swelling (waram) that accompanies them. ${ }^{57}$ Moreover, even though he

\footnotetext{
${ }^{55}$ L. I. Conrad, 'Arabic Plague Chronologies: Social and Historical Factors in the Formation of a Literary Genre', Studia Islamica, 54 (1981), 51-93, 66; al-Nawawī, al-Minhāj fì sharḥ ṣaḥ̄ḥ Muslim ibn Hajjāj: sharh al-Nawawì alā Muslim (Amman: Bayt al-Afākir al-Dawliyya, n.d.), Intro., ch. 5, 61.

${ }^{56}$ al-Nawawī, ibid., bk. 39, ch. 32, no. 92, 2218. Compare with Conrad, op. cit. (note 9), 297. Since there is a Prophetic tradition that refers to marāq (groin), Conrad assumed that al-Nawawī’s original word was erroneously transcribed by the copyist as marāfiq (elbows). Ibn Hajar al-'Asqalānī (d. 1449) thought similarly since he also uses marāq (groin) while quoting this passage from al-Nawawī. However, a century earlier, Ibn Abī Hajala used marāfiq (elbows) when quoting from al-Nawawī. Given the larger context in which al-Nawawì was writing, 'elbows' makes sense since he also distinguishes between pustules and the glandular swelling itself. The restriction to the arm also concurs with what we find in the post-1258 Syrian medical commentaries of al-Sāmirī and Ibn al-Quff; Ibn Hajar al-'Asqalānī, Badhl al-mā'ūn fí al-fadl al-țā'ūn, A. I. A. Q. al-Kātib (ed.) (Riyadh: Dār al-'Āṣima, n.d.), 97; Ibn Abī Hajala, Daf al-niqma fì șalāh 'alā nabī al-raḥma, Madrid, Escorial Library, MS 1772, fol. 41a.

${ }^{57}$ Vladimir V. Nikiforov, et al., 'Plague: Clinics, Diagnosis and Treatment', in R. Yang and A. Anisimov (eds), Yersinia pestis: Retrospective and Perspective (Berlin: Springer, 2016), 293-312, especially figures $11.2 \mathrm{M}, \mathrm{O}$ and $\mathrm{P}$.
} 
suggests that the sores erupt throughout the body, he also localises them to one region of the body: armpits, elbows and hands. No medical writer prior to al-Nawawī had ever identified the presence of sores or ulcers in addition to the swellings, nor the distinct purplish hue that is prominent on the skin as the ulcer grows. In fact, the medical works known to al-Nawawī, such as Avicenna's Canon of Medicine, never even mentioned the fiery inflammation (lahi $b)$ that accompanies the eruption of the sores.

This movement beyond Avicenna is also seen in the Prophetic Medicine of al-Dhahabī, the Damascene chronicler we have already encountered who studied under one of the few eyewitnesses to the assault on Baghdad. When summarising Avicenna's description of plague buboes in his Prophetic Medicine, a text that brings together Galenic/Avicennan medicine and Prophetic hadith, he does not mention inflammation. Yet, when providing what he takes to be the medical understanding of plague current at his time (circa 1330), al-Dhahabì emphasises both the frequent occurrence of the bubo in the armpits and that the bubo is accompanied by inflammation. ${ }^{58}$

\section{When a $W a b \bar{a}^{3}$ is not a Tāün: The origins of miasm at Baghdad}

As noted, almost every single author who recorded an outbreak of disease in any region soon after the fall of Baghdad in 1258 used the term $w a b \vec{a}$. Conrad has shown that it was only in the mid-thirteenth century that $t \bar{a} \bar{u} n$ (plague) came to be widely seen as a special type of $w a b \bar{a}^{2}$ (epidemic), even if the medical understanding of $t \bar{a} \bar{u} \bar{n}$ that undergirded this shift can be found in the medical encyclopaedias of al-Majūsī (d. after 977) and Avicenna. ${ }^{59}$ These encyclopaedists explained that an epidemic fever (al-hummā al-wabiyya) was caused by a corruption in the substance of air, which when breathed in ruins the spirit in the heart. This bad spirit is then distributed to the rest of the body through the arteries and so results in a person falling ill. Plague is considered to be a highly lethal epidemic fever that has specific, distinguishing characteristics (such as painful swellings), but also shares other symptoms with many epidemic fevers, such as palpitation, delirium, fainting, etc. This is what allows al-Nawawī, who had studied Avicenna's Canon, to state confidently: 'Every plague ( $t \bar{a} \bar{u} \bar{n})$ is an epidemic $\left(w a b \bar{a}^{3}\right)$ but not every epidemic is a plague'. ${ }^{60}$ In terms of what can corrupt the air so much that it results in lethal epidemic outbreaks, Avicenna suggests many possible causes, both celestial (e.g. meteorites) and terrestrial (e.g. miasmas arising from dead bodies or brackish water). Moreover, the corrupted air can travel from one region to another through 'winds that [may] bring to a good, healthy place bad, smoky vapours from distant places wherein there are [either] wide beds of shallow, brackish water, or decaying corpses due to massacres or a deadly epidemic such that they have not been buried or burned'. ${ }^{61}$

This miasmatic explanation of the 1258 outbreaks is only invoked by historians after al-Nawawi. Recall that Abū Shāma was surprised by the outbreak of a lethal epidemic in 1258, and neither Bar Hebraeus nor Ibn Khallikān connected the onset of the epidemic to the killings in Baghdad. Ibn Wāșil, writing in Cairo in the final quarter of the thirteenth century, is the first chronicler to explicitly claim that an epidemic broke out in Syria and Egypt due to the miasma spreading from Baghdad. It is worth reminding ourselves that he is also the first one to use the term $t \bar{a}^{c} \bar{u} n$ (in addition to $w a b \vec{a}$ ) to refer to these outbreaks, and that he was on friendly terms with the leading Cairene physician of the thirteenth century, Ibn al-Nafiss (d. 1288). His debt to the reigning medical understanding is apparent when he explains that the abundance of corpses that resulted from the Mongol slaughter in Baghdad is what corrupted the temperament of the air, resulting in plague and an epidemic in Syria and Egypt. He also

\footnotetext{
${ }^{58}$ al-Dhahabī, al-Ṭibb al-nabawī, A. R. al-Badrawi (ed.) (Beirut: Dār Ihyāà al-'Ulūm, 1990), 266-7; Cyril Elgood, 'Tibb-ulNabbi or Medicine of the Prophet', Osiris, 14 (1962): 33-192, 149-50. Elgood incorrectly assigns the text to Jalāl al-Dīn al-Suyūṭī (d. 1505); see Irmeli Perho, The Prophet's Medicine: A Creation of the Muslim Traditionist Scholars (Helsinki: Kokemäki, 1995), $14,36$.

${ }^{59}$ Conrad, op. cit. (note 9).

${ }^{60}$ al-Nawawī, op. cit. (note 55), bk. 39, ch. 32, no. 92 (2218); Conrad, op. cit. (note 9); Fancy, op. cit. (note 8). See also EI2, s.v. 'Wabā'” (B. Shoshan and D. Panzac).

${ }^{61}$ Ibn Sīnā, al-Qānūn fĩ al-țibb, M. A. al-Dinnawi (ed.) (Beirut: Dār al-Kutub al-'Ilmiyya, 1999), III: 87.
} 
cites Galen's account of mass killing in Greece causing an epidemic in Nubia to support the claim that wind blowing over corpses in Baghdad could have caused the epidemic in distant Syria. ${ }^{62}$

When we move to the second generation of historians, we see an intriguing bifurcation. The first group picked up on the miasmatic explanation while the second did not. The anonymous author of al-Hawādith al-jāmi'a, al-Dhahabī and al-Yūnīnī all link the disease outbreaks in Baghdad, Egypt and/or Syria to the corruption spreading from Baghdad. ${ }^{63}$ The Hawädith and al-Dhahabì's text provide the most detailed descriptions of the corruption arising from the corpses. The second group - Abu al-Fidā', al-'Umarī and Ibn al-Wardī - does not provide any miasmatic explanation for the disease outbreaks.

Those Black Death historians who adopted miasmatic views recycled much material from the second generation and linked the epidemic outbreaks to the miasma spreading from the corpses of Baghdad. Ibn Kathīr, in fact, goes further and says,

When rain fell upon [the heaped corpses], it changed their forms, giving off a horrible smell into the region from their bodies, thus changing the air. This caused a severe epidemic ( $w a b \vec{a})$ such that it was transmitted to $\left(t^{\prime} a d d a\right)$ the air and spread to Syria. Many people died from the change in the air and the corruption of the wind. ${ }^{64}$

Even though the fourth-generation historians rely on their predecessors, we saw that none record a plague outbreak in Syria in 1258. Moreover, except for the Yemeni author al-Malik al-Ashraf, none of them connect the Syrian epidemic outbreak to the miasma spreading from Baghdad. In other words, they return to the perspective of the original observers who drew no direct association between the two events. Moreover, even al-Malik al-Ashraf only does so by quoting al-Dhahabī. Thus, not only does the epidemic in Baghdad fall out of the Arabic historiographical tradition by the fifteenth century, but even the Syrian epidemic is no longer linked to a miasma spreading from Baghdad nor is it identified specifically as plague.

It should be stressed that for none of these authors, whether historians or physicians, were the Mongols seen as bringing the disease to the region (as we would now understand plague transmission in a biomedical framework). For Ibn Wāsil, the anonymous author of Hawädith, and those who followed them, the Mongols caused an epidemic to erupt by the havoc they wrought, the dead bodies of the slaughter giving off smells that penetrated and corrupted the temperament of the ambient air. Moreover, for a corruption to cause a lethal plague outbreak rather than a general epidemic (even if it was lethal), the corruption would have to be severe enough for the air to attain a poisonous quality. This insight helps us understand why chroniclers could and did speak of 'only' an epidemic, albeit lethal, in Baghdad, but an epidemic and plague in Syria. Corrupt air carried by winds that have passed over other corrupt bodies and/or locales can gain in strength, such that by the time this miasma arrived in Syria it could have turned poisonous enough to cause a plague outbreak. In fact, just how far miasmas could spread can be seen in the following passage from the Tunisian historian Ibn Qunfudh who, writing in the fifteenth century, observed:

In this year [i.e. 656/1258], the people of Tunis and other (places) were engulfed by a disease. The Sultan Mustansar fell ill for several days, then he recovered. It was said: its cause was the stench that arrived in Ifriqiyya of those killed in Baghdad by the Mongols at that time. ${ }^{65}$

\footnotetext{
${ }^{62}$ Ibn Wāșil, op. cit. (note 23), fol. 130b. On Ibn Wāșil's interactions with Ibn al-Nafĩs, see Joseph Schacht and Max Meyerhof, The Theologus Autodidactus of Ibn al-Nafiss, edited with an introduction, translation and notes (Oxford: Oxford University Press, 1968), 14-15, 76.

${ }^{63}$ Ibn Fuwațī, op. cit. (note 26), 237; al-Dhahabī, op. cit. (note 28), LXVIII: 248; al-Yūnīnī, op. cit. (note 28), I: 91, $174-5,187$.

${ }^{64} \mathrm{Ibn}$ Kathīr, op. cit. (note 40), XIII: 203. His use of the term ta'adda, a word from the same root as 'adwa (contagion), signals that he is invested in the historical and contemporary theological debates over contagion.

${ }^{65}$ Ibn Qunfudh, al-Fārisiyya fì mabādi al-dawla al-ḥafșiyya, M. S. al-Nayfar and A. M. al-Turkī (eds) (Tunis: al-Dār al-Tūnisiyya li-1-Nashr, 1968), 121. Our thanks to Ramzi Rouighi for providing us further information on Ibn Qunfudh's reference to Baghdad.
} 
We should add that there seems to have been no contemporary witness of the siege of Baghdad who offered a clinically precise description of the disease. The vast majority of scholars in Baghdad (indeed, the population at large) was killed at the hands of either the Mongols or the disease. Consequently, subsequent chroniclers asserted the existence of plague in Syria confidently, but not in Baghdad, even if the miasma began in the latter city. This is perhaps most apparent in the work of the Persian physician al-Shīrāzī who, despite recording the changes in how plague was understood by contemporary physicians, never reports an outbreak of $t \bar{a}^{\dagger} \bar{u} n$ in his medical commentary or his chronicle, even if he lists two other $w a b \vec{a} \vec{a}^{3}$ outbreaks during Hülegü's campaign across Iran. ${ }^{66}$

Remarkably, the ultimate failure of the Baghdad-Syria-Egypt events of 1258 to develop into a locus classicus of miasmatic processes opened the way to framing the next wave of plague outbreaks, the Black Death, in precisely those terms. The key figure in this transition was the scholar and poet Ibn Abī Hajala (1325-75), who posited miasmas (and winds spreading them) as a major cause of disease outbreaks throughout Islamic history. ${ }^{67}$ Since the first Muslim conquests of Syria and Iran in the seventh century took place against the backdrop of the first plague pandemic, these early encounters with plague left a deep mark on Islamic theology. The events raised a classic point of debate in Islamic theology: whether to stay in a plague-ridden area and accept the will of God, or to flee. ${ }^{68}$ A Prophetic injunction against fleeing, recorded in a famous hadith, framed much of the early eighth- and ninth-century debates. The communal memory of the high mortality rates of these outbreaks was subsequently enshrined by religious scholars who in the ninth century generated lists of plague outbreaks during the first two centuries of Islam. This tradition of documenting plague outbreaks was synthesised by al-Nawawi in the midst of his commentary on Muslim's hadith collection as he tried to ascertain the exact date of a particular plague outbreak (the Plague of Torrent). ${ }^{69}$ At no point in the earlier tradition, or in al-Nawawì's synthesis, are the outbreaks explained using the theory of miasmatic corruption of air. Yet, when we get to Ibn Abī Hajala's Daf al-niqma (Repelling the Trial), miasmas are used to explain earlier plague outbreaks, including at least one from the First century of Islam.

Repelling the Trial is a rich, literary text by a religious scholar who was trying to understand and put into words the unspeakable death and destruction of his times. ${ }^{70}$ The Prophetic hadith on not to flee a plague-ridden area features prominently throughout this work. Yet, Ibn Abī Hajala also tries to incorporate the latest medical understanding of the disease within his text. Even before he gets to listing all the plague outbreaks in chapter 7, Ibn Abī Hajala notes in chapter 4 that plague is caused by a corruption of the air. He quotes directly from Ibn al-Nafis's Epitome - a popular abridgment of Avicenna's Canon - to defend this claim: 'The epidemic $(a l-w a b \vec{a})$ is a corruption that takes place in the substance of air due to celestial or earthly causes'. Earlier in this same chapter, Ibn Abī Hajala affirms the dictum that 'every plague is an epidemic but not every epidemic is a plague', and reiterates that plague outbreaks prevail in times of epidemics and in regions predisposed to epidemics. ${ }^{71} \mathrm{He}$ also asserts that miasmatic corruptions can be carried over to different places by the winds. The clearest example of that is in his reporting of an epidemic of cough and cold in the ninth century that afflicted people across Iran and Iraq due to winds that carried corrupt air all the way from Central Asia. ${ }^{72}$ The corruptions themselves could have various causes. For example, he says that a bright star was visible in the sky for several nights in October 1034 which resulted in a plague outbreak. Many people died in Shiraz due to

\footnotetext{
${ }^{66}$ Green, op. cit. (note 2).

${ }^{67}$ On Ibn Abī Hajala, see Beatrice Gruendler, 'Ibn Abī Hajala (1325-1375)', in J. E. Lowry and D. J. Stewart (eds), Essays in Arabic Literary Biography. II: 1350-1850 (Wiesbaden: Harrassowitz, 2009), 118-26.

${ }^{68}$ Justin Stearns, 'Amwās, plague of, Encyclopedia of Islam, 3rd edn, K. Fleet, et al. (eds) (Leiden: Brill, 2016), II: 28-9.

${ }^{69}$ Conrad, op. cit. (note 55).

${ }^{70}$ Andreas Herdt, 'Ibn Abī Hağalah und sein Traktat "Das Feien gegen jedwede Widerwärtigkeit mittels des Bittgebets für den Propheten der Gnade" (Daf' al-niqma bi-ṣ-șalāh 'alā nabī ar-rahmāh)', in N. Papoutsakis and S. von Hees (eds), The Sultan's Anthologist: Ibn Ab̄i Hăgalah and His Work (Baden-Baden: Ergon Verlag, 2018), 209-36, 234.

${ }^{71}$ Ibn Abī Hajala, op. cit. (note 56), fol. 40b.

${ }^{72}$ Herdt, op. cit. (note 70), 229. There is a slight corruption in the date listed in the manuscript; as Herdt notes, it is very likely $240 / 854$ and not 204/819.
} 
this plague and their smell carried as far away as Baghdad where it led to a plague outbreak killing over 70000 people. ${ }^{73}$ At other times, the connection is not made explicitly but is implied. For example, he states that, in the 705 plague outbreak, people across Iraq and Syria were subjected to not only death by plague but also by the sword thanks to the bloody battles under the Umayyad general, al-Hajjāj. This is despite the fact that these battles had occurred over a decade earlier, including the bloody siege and conquest of Mecca (692). ${ }^{74}$ Corruption (even in prior years) and winds thus play an important role in many of the thirty-three epidemics and plagues he lists.

Despite this interest in the relationship between corruption and epidemics, or perhaps because of it as we shall argue, Ibn Abī Hajala does not report any epidemic or plague outbreak when he describes the Mongol conquests of the Middle East (1218-20, and in the 1250s). He knew al-Dhahabì's and Ibn Kathīr's texts well (he even cites them in the course of his work), yet he never mentions an epidemic outbreak in 1258, despite the fact that he lists two post-Mongol invasion epidemic outbreaks during the thirteenth century: one in Egypt in 1236 and another in Syria in $1296 .{ }^{75}$ Instead, he classifies the entire set of Mongol conquests, from the first ones under Chinggis Khan to those under Hülegü Khan three decades later, as the twenty-eighth plague. His reasons for doing so are partly revealed in the introduction to the chapter where these plagues are listed:

On the plagues that have struck mankind [generally], and [specifically] those that have occurred since the rise of Islam to the present year, as well as what enemy oppressors have perpetrated by way of war, which is more [deadly] than the plague, particularly [that waged by] the depraved Tatars during the reign of Hülegü, so as to inspire sorrow for all that has been lost and provide consolation for the great mass of those who perished. ${ }^{76}$

The account of the twenty-eighth plague uses very evocative prose to capture the devastation the Mongols wreaked on the Islamic Middle East. He deems this destruction worse than the Biblical plagues, since the destruction was more widespread and not restricted to one region or community. The tone is very apocalyptic since he compares the Mongols to the Gog and Magog, and the Antichrist. ${ }^{77}$ He refers to winds and moving clouds often in the narrative to highlight the speed of the conquest, which also connects with his use of winds to explain the spread of miasmatic corruption in earlier plagues.

The allusion to epidemics is perhaps closest when he describes the second Mongol wave, which resulted in the destruction of Baghdad. He begins by first stating on his own authority ('I say') that 'these venomous scorpions continued to move and their epidemic winds (ahwiyyatuhum al-wab'iyya) continued to blow'. These winds first struck the Khwarizmshāh who was in between the Mongols and Baghdad, after which the Mongols descended on Baghdad in 1258 and utterly wiped out its population and 'corrupted the land (afsidiu al-bilād)'. Only those who hid in the pillaging or under the earth (taht al-turāb) were saved. ${ }^{78}$ The imagery in Ibn Abì Hajala thus takes the descriptions found in the Hawädith and the works of al-Dhahabi for the siege of Baghdad specifically, and uses them to describe how Hülegü's armies corrupted all of the eastern lands of Islam.

Given his emphasis on corruption ( $f a s \bar{a} d)$, why does Ibn Abī Hajala not record an incidence of plague or epidemic during the Mongol conquests of Iraq and Iran? We can hazard two possible reasons. First,

\footnotetext{
${ }^{73}$ Ibn Abī Hajala, op. cit. (note 56), fol. 66b.

${ }^{74}$ Ibid., fol. 63a.

${ }^{75}$ The latter is reported as $w a b \vec{a}$ by Ibn Abī Hajala but as a time when there was widespread inflation and mass mortality ( ghilä wa-l-fanä) by Ibn Kathīr; Ibn Abi Hajala, op. cit. (note 56), fol. 74a; Ibn Kathīr, op. cit. (note 40), XIII: 343.

${ }^{76}$ Our thanks to Matthew Melvin-Koushki for providing this new translation of the opening to the seventh section of Ibn Abi Hajala's text. It differs in several important respects from the translation offered by Conrad, op. cit. (note 55), 74. The manuscript copyist (or Ibn Abī Hajala himself) transcribed Hülegü’s name awkwardly, which has led past historians to assume that the name given is Qalāwūn. However, we are certain that Hülegü is intended here since the name is transcribed almost identically (h-l-ā-w-n) when referring to the siege of Baghdad; Ibn Abī Hajala, op. cit. (note 56), fols. 59b, 72b.

${ }^{77}$ Ibn Abī Hajala, op. cit. (note 56), fol. 71b.

${ }^{78}$ Ibid., fol. $72 \mathrm{a}-\mathrm{b}$.
} 
even though Ibn Abī Hajala lists each item as a plague, he is really more interested in recording mass, at times inexplicable, death, in order to 'provide some consolation for the great mass of those who have perished' in the plague outbreaks during his lifetime (which he says number half the population of the known world). ${ }^{79}$ The deaths by the swords of the Mongols far outnumber the deaths by disease during 1258. Alternatively, since Ibn Abī Hajala accepted the medical explanation that plagues are caused by corrupt air, he might have struggled to comprehend why the mass devastation caused by Chinggis Khan (and then Hülegü) should have only resulted in one plague outbreak over the course of a few months in Syria in 1258 and no more. His own lived experience with the plague, as well as his recording of previous plagues ( $t \bar{a} \bar{u} n$, specifically), revealed to him that these outbreaks tended to be more widespread, which made sense since miasmas are spread by winds. And as the scholar who seemed to have been most invested in the contemporary miasmatic explanation of plague, he may have come to the conclusion that the disease outbreak in Syria should not be classified as plague.

\section{A cataclysm erased: the Black Death and a new historiography of plague}

As we have seen, the motive for listing plague outbreaks originated among hadith scholars and theologians interested in debates over contagion and what plague signified for the Muslim community; hence, these lists focussed on the first two centuries after the Prophet, which is also the case with al-Nawawī. An important exception to this focus was Ibn al-Jawzī (d. 1201), a Baghdadi jurist who produced a list of 'droughts and widespread death', and one of 'earthquakes and miracles' leading up to the mid-twelfth century. These were not specifically lists of plagues, since of the twelve events recorded in his list of 'droughts and widespread death' only three are classified as plague (ța'ūu $n)$, all prior to $750{ }^{80} \mathrm{As}$ Herdt has shown, Ibn Abī Hajala incorporated many events from Ibn al-Jawzî̀s list of 'droughts and widespread death', but reclassified them as plagues. In fact, he even incorporated one event from Ibn al-Jawzî̀s list of earthquakes since it accorded well with his larger interest in miasmas and corrupting winds. ${ }^{81}$

Another Black Death generation author who used Ibn al-Jawzî̀s list(s) to enumerate historical plagues beyond the first two centuries of Islam was Ibn Khātima (d. 1369), a physician, grammarian and historian from Almeria, who produced a list of plagues from 639 up to 1071-2. The list is included in his plague tract, a genre that came into being during the mid-fourteenth century; indeed, his tract may be the first of its kind in Arabic. ${ }^{82}$ Ibn Khātima includes seven outbreaks from the tenth century onwards from Ibn al-Jawzî̀s list of widespread death, and adds to that three lethal, plague-like events in Cordoba (900-1, 946-7 and 1010-11), not found in Ibn al-Jawzī's list.

More influential for writers in the Mamluk region, however, was Ibn Abī Hajala's list of plagues. For example, of the eighteen disease outbreaks recorded by Ibn Abī Hajala during the Abbasid period (750-1258), Ibn Hajar al-'Asqalānī (d. 1449), an Egyptian hadith scholar, judge and historian, incorporates ten outbreaks. Moreover, in most cases, Ibn Hajar lists these outbreaks as plague (țātun even if Ibn Abī Hajala had classified them as $w a b \bar{a}$ (e.g. the outbreaks of 1032 and 1236). Only rarely

\footnotetext{
${ }^{79}$ Ibid., fol. $75 \mathrm{a}$.

${ }^{80}$ Ibn al-Jawzī, al-Mudhish, M. al-Qabbānī (ed.) (Beirut: n.p., 1981), 70-5.

${ }^{81}$ Herdt, op. cit. (note 70), 229.

${ }^{82}$ We were unable to obtain a copy of the recent edition of Ibn Khātima's text: Thalāth rasä̉il andalusiyya fí al-țāīun al-jārif, M. Hasan (ed.) (Tunis: Bayt al-Hikma, 2013). This edition also includes Ibn al-Khațīb’s plague tract (discussed below) and the extant portion of the treatise of al-Shaqūrī (d. after 1369), a jurist and physician to the Nasrid court in Granada. In the absence of this edition or access to the manuscript, we have consulted the following translation for Ibn Khātima: Abū Ğa far ibn Hātima al-Anșārī, La grande peste en Espagne musulmane au XIVe siècle: le récit d'un contemporain de la pandémie du XIVe siècle, S. Gigandet (ed. and trans.) (Damascus: Institut français du Proche-Orient, 2010). As yet unpublished is the recently discovered Ișläh al-niyya fì l-mas'ala al-țāìniyya (Correcting the Intention on the Issue of the Plague) by the Almerian cleric, notary, and poet, Ibn Mushtamil al-Bilyānī (d. 1363).
} 
(e.g. the outbreak of 1200) does Ibn Hajar clarify that the outbreak was not plague. He also explicitly cites Ibn Abī Hajala's account of the catastrophic plague outbreak of $1348 .{ }^{83}$ It is no surprise, therefore, that Ibn Hajar does not include the outbreaks of 1258 in his list since they are not present in his main source. The same is true of the other fifteenth-century chroniclers, al-Maqrīzi and Ibn Taghrībirdī, who also knew and used Ibn Abī Hajala's work. ${ }^{84}$ The 1258 plague outbreak thus disappeared from the view not simply of these three key fifteenth-century Syro-Egyptian scholars of plague, but also of modern scholars who have relied extensively on them.

The erasure of the thirteenth-century plague outbreaks from Islamic plague historiography also affected the framing of the even more cataclysmic fourteenth-century pandemic. As noted at the beginning of this essay, aside from John Norris, historians have relied upon the literary accounts found in the plague tracts of the fourteenth century that suggest that the 1348/9 plague outbreaks in the Mediterranean were a culmination of the westward movement of plague across Central Asia during the 1330s and 1340s. Ibn al-Wardī, Ibn Khātima and Ibn al-Khațīb all provide such an origin narrative, suggesting that they were all recycling a common template of news. ${ }^{85}$ Ibn Khātima describes the origins of this plague thus:

There are disagreements about when the epidemic started versus where it started. I have been told from a reliable source from Christian traders who came to us in Almería that it had started in the country of Hițāh, Cathay, a name which in the language of foreigners designates China, as I learned from trustworthy travelers from Samarqand; China is one of the most populated countries in the Orient. The plague continued to spread from Cathay and reached the neighbouring countries as far as Iraq and the territories of Turkey. Other Christians arriving with us also reported to me that they had learned that it had started in Abyssinia and had spread to neighbouring areas and countries as far as Egypt and Syria. ${ }^{86}$

Ibn Khātima is the only one who mentions the alternate Abyssinia story, and the only one that refers to Khițai without referencing China separately. Ibn al-Wardī and Ibn al-Khațīb, on the other hand, distinguish between Khitai and China, and both also put a precise date on the beginning of this outbreak: $734 \mathrm{AH}$ (1333-4 CE). ${ }^{87}$ These differences suggest that whatever was in the original reports they heard from travellers and merchants, each of them moulded these reports into their accounts based on their specific understanding of the disease and geography. For example, neither Ibn Khātima nor Ibn al-Wardī appeal to miasmas to explain what caused this outbreak (Ibn al-Wardī does not refer to miasmas when reporting the incidence of plague in Syria in 1258 either). On the other hand, Ibn al-Khațīb states on the authority of the traveller Ibn Bațutụa (d. 1377) and others that the plague began in the land of Khitai and China when the air was corrupted by blowing over dead corpses from the wars in the region in 1333/4. This date accords with the accession of Toghan-Temür to the throne of Mongolia and China, and the War of the Two Capitals that preceded it. The war, centred in the region of Liaodong (far northeast China), was so devastating that, according to the fourteenth-century Official History of the Yuan Dynasty, 'no residents were

\footnotetext{
${ }^{83}$ Ibn Hajar al-'Asqalānī, op. cit. (note 56), 368.

${ }^{84} \mathrm{Al}$-Maqrīzî̀'s report, for example, on the number of people who died within Cairo's city walls during the outbreak of 1348 is based on Ibn Abī Hajala's text; David Ayalon, 'Regarding Population Estimates in the Countries of Medieval Islam', Journal of the Economic and Social History of the Orient, 28 (1985), 1-19, 7-10.

${ }^{85} \mathrm{Ibn}$ Abī Hajala does not explain the origins of the 1348/9 outbreak in his list but includes Ibn al-Wardī's treatise on plague at the end of his own tract.

${ }^{86}$ Gigandet, op. cit. (note 82), 19-20. Ibn Khātima's suggestion that there was an alternate origin of plague, in Abyssinia (presumably referring to Ethiopia), is significant; see Fancy, op. cit. (note 8), on a report of plague in Ethiopia prior to 1242. Ibn Abī Hajala lists a plague outbreak in Egypt in 1295.

${ }^{87}$ Ibn Abī Hajala, op. cit. (note 56), fol. 81a; Dols, 'Ibn al-Wardī’s Risālah,' op. cit. (note 1), 448; M. J. Müller, 'Ibnulkhatibs Bericht über die Pest', Sitzungsberichte der königliche bayerischen Akademie der Wissenschaften zu München, 2 (1863), 1-34, 9.
} 
left in the countryside'. ${ }^{88}$ In fact, rebellions and wars broke out after Toghan-Temür's succession too, one of which led Ibn Bațutta to flee the Yuan capital, Khan Baliq (Beijing) - a region Ibn Bațūța situates in Khițai - and return to southern China. ${ }^{89} \mathrm{Ibn}$ al-Khațîb, like Ibn Wāṣil and Ibn Abì Hajala, was firmly committed to a miasmatic explanation for the cause and spread of plagues and so would have latched on to this report about wars and rebellions in China that killed so many people. In fact, we know that Ibn al-Khațīb corresponded with Ibn Abī Hajala in the 1350s, prior to composing his plague tract. ${ }^{90}$ Ibn al-Wardī, Ibn Khātima, and Ibn al-Khațīb all had different geographical imaginaries, reflecting the knowledge current within their social and intellectual circles. For Ibn Khātima, Khițai and China interchangeably refer to the entire region from Guangzhou to Beijing, whereas Ibn al-Khațīb follows Ibn Bațūtạ's usage of these terms to refer to northern and southern China, respectively. Ibn al-Wardī refers to the region north of China as the 'land of darkness' and uses Khitai to refer to the former territories of the Qara-Khitai empire (i.e. modern-day Kyrgyzstan and Xinjiang). Nonetheless, they all suggest that the plague began in the region north of Beijing. ${ }^{91}$

Even if only Ibn al-Khatịb directly appealed to miasmas to explain the Black Death of 1348/9, this explanation was already gaining a foothold in the second half of the fourteenth century. Ibn Abī Hajala incorporated Ibn al-Wardī's plague tract at the end of his own work thus encouraging others to read it in conjunction with his own miasmatic explanations of earlier plagues. Ibn Khătima does not record the event that originally corrupted the air to generate the plague in China, but in the same tract, he explains how miasmas are generated and cause plague. Thus, for post-Black Death writers like Ibn Abī Hajala and Ibn al-Khațîb, if mass deaths in one region could cause plagues that could affect people in faraway lands (deaths in Shiraz causing a plague in Baghdad in 1034, or the destruction in China causing the 1334-49 plague outbreak across Eurasia and North Africa), then the widespread destruction caused by the Mongol invasions and destruction of Baghdad should have caused a massive, global plague outbreak in the 1220s and 1258, and not just one in Syria (and possibly Egypt). This is perhaps why, in the post-1348 writings, the 1258 outbreak seemed less than 'plague-like' and dropped out of accounts - it just did not accord with their personal experience and medical understanding of plague. Even Ibn al-Wardī, who had acknowledged the 1258 outbreak in his supplement to Abū al-Fidā"s chronicle, did not connect it to the Mongol killings in Baghdad. Their narrative choices stuck.

\section{Conclusion}

So far as we know now, the impact of plague on western Asian human populations in the 1250s was relatively minimal. Our evidence documents plague-like outbreaks only in 1258, even though Mongol assaults on Syria were repeated up to 1260. If Hülegü's campaign was indeed the event that brought a strain of Yersinia pestis to the Caucasus or the surrounding regions where the bacterium established a reservoir, that reservoir truly was occult, not witnessed in any outbreaks that have yet come into the

\footnotetext{
${ }^{88}$ David Robinson, Empire's Twilight: Northeast Asia under the Mongols (Cambridge, MA: Harvard University Asia Center, 2009), 40.

${ }^{89}$ Tim Mackintosh-Smith (ed.), The Travels of Ibn Battutah (London: Picador, 2002), 17, 273. Ibn Batțūṭa would have been in China during the reign of Toghan-Temür for a few months between 1345 and 1346. Some of what he reports does not seem correct, e.g. he reports that the Mongol ruler was killed in 1346 which certainly cannot refer to Toghan-Temür who lived for two more decades.

${ }^{90}$ On evidence for literary exchanges between Ibn Abī Hajala and Ibn al-Khațīb, see Papoutsakis and von Hees, op. cit. (note 70), 35, 188 and $343 \mathrm{n} .128$. Whether or not the two poets also exchanged their writings on plague is not yet documented.

${ }^{91}$ On what seem to be plague outbreaks in Yuan China starting in the 1330s and 1350-60s, see Stephen G. Haw, 'The Overview of the Unified Territories of the Great Yuan and Marco Polo's Account of the Empire of Qubilai Qa'an', Zeitschrift der Deutschen Morgenländischen Gesellschaft, 170, 1 (2020), 215-36, 228-9; Timothy Brook, Great State: China and the World (London: Profile, 2019), 70-1.
} 
historical record prior to the 1330s. ${ }^{92}$ The Mongols of the newly established Ilkhanate consolidated their control over Iran and centred their activities at the flourishing commercial hub of Tabriz and a nearby intellectual centre at Maragha (where al-Shīrāzī spent part of his career) ${ }^{93}$ If the term Pax Mongolica applies to any period, it was the late thirteenth century and early fourteenth century, during which time we do not hear of any major, regional outbreaks. Starting in the 1330s, however, a number of as yet unconnected events seem to point to an expansion of plague. Beyond the still mysterious collapse of the Ilkhanate and the abandonment by Italian merchants of trade through Tabriz, ${ }^{94}$ we know of a high-order earthquake on 21 October 1336 centred on the eastern edge of the Caspian Sea that is said by a contemporary chronicler to have caused at least 30000 deaths due to an ensuing epidemic. ${ }^{95}$ By 1346 , plague was widespread throughout the Golden Horde. Transmission to the west, of course, is the foundation of Black Death narratives to date, and we have demonstrated now why fourteenth-century chroniclers in Syria and Egypt should have been persuaded by Ibn Battūta's account that the plague they were witnessing in the Mediterranean was due to miasmas arising from the killing fields of northern China. Ibn al-Wardī's widely influential account (early 1349) of plague afflicting virtually all parts of Asia would have surely dissuaded anyone from noticing, for example, that Samarqand experienced its most devastating plague outbreak not before the outbreaks in the Golden Horde and the Black Sea (as the rapid westward-transmission narrative would lead us to expect), but afterwards. ${ }^{96}$

In the absence of confirmation from aDNA, we cannot say with certainty that the bacterium $Y$. pestis was involved in the Fall of Baghdad. Nevertheless, our investigations have established that a series of contemporary observers in western Asia - historical chroniclers, medical writers and theological commentators - and their immediate successors believed the 1258 outbreaks had involved the buboproducing disease they called $t \bar{a}^{c} \bar{u} n$ - the same term they used to describe the disease outbreaks of the seventh and eighth centuries in which we know now (from European aDNA evidence) that $Y$. pestis was involved. We know plague is primarily a rodent disease and, as such, has likely always moved in and out of human awareness. We imagine that, however awful the devastation of 1258 was, the human outbreak burned out quickly because it was the result of imported grain supplies and had not yet established a local rodent reservoir. The process of focalisation would have likely occurred further north, somewhere in or near the Caucasus Mountains among local rodents, invisible to human perception.

Bacteria and 'plague reservoirs' are, of course, concepts that would have been entirely foreign to the Syrian and Egyptian writers of specialised plague treatises in 1349 and beyond. They had all been born long after the immediate Mongol threat had subsided. They had no conceptual framework, not even Ibn Abī Hajala's 'winds', to think about a century-long disease event that included decades of quiescence.

\footnotetext{
${ }^{92}$ Green, op. cit. (note 2).

${ }^{93}$ Johannes Preiser-Kapeller, 'Civitas Thauris: The Significance of Tabriz in the Spatial Frameworks of Christian Merchants and Ecclesiastics in the 13th and 14th Centuries', in J. Pfeiffer (ed.), Politics, Patronage and the Transmission of Knowledge in 13th-15th Century Tabriz (Leiden: Brill, 2013), 249-99.

${ }^{94}$ Patrick Wing, "Rich in Goods and Abounding in Wealth": The Ilkhanid and Post-Ilkhanid Ruling Elite and the Politics of Commercial Life at Tabriz, 1250-1400,' in Pfeiffer (ed.), ibid, 301-20.

${ }^{95}$ Timur Khaydarov identified a 1336-37 earthquake and subsequent epidemic, killing thousands of people, in the Persian chronicle of Fașịh Ạ̣mad b. Jalāl al-Dīn Muhammad Khvāfī, Mujmal-i Fașịhī; T. F. Hajdarov [Khaydarov], 'Epidemii chumy v kaspiyskom regione (konets xiv - nachalo xv vv.) [Epidemics of Plague in the Caspian Region (End of the XIV - Beginning of the XV Centuries)],' Zolotoordynskaya Tsivilizatsiya [Golden Horde Civilisation], 10 (2018), 304-9. The earthquake has been confirmed geologically by Manuel Berberian who identifies the quake as probably greater than a 7 on the 10-point Richter scale; 'Pre-1900 Coseismic Surface Faulting,' Developments in Earth Surface Processes, 17 (2014): 183-238. Our thanks to Eugene Clay for the latter reference.

${ }^{96}$ In his aforementioned chronicle, the scrupulous researcher Ibn Shākir posits an eastward movement of plague from the Caspian Sea towards the regions around Issyk Kul: 'No one knows how many died in the Eastern land but it is said that, in Samarqand, from Shawwal 10 [i.e. January 1, 1349] till the end of Dhū al-Qa'da [i.e. February 15, 1349] 236,000 funerals were counted leaving its gates. This epidemic disease $[w a b \vec{a}]$ arrived from Turkestan, the land of the infidels, then went from there to the region of Ṣighūn (?), Kashgar, Altanās (?), Ferghana, and these surroundings'; Ibn Shākir al-Kutubī, 'Uyūn al-Tawārīkh, Istanbul, Topkapı Sarayı Müzesi Kütüphanesi, MS Ahmet III 2922, vol. 24, fol. 95a. We discovered this text after Tarek Sabraa and Stuart Borsch alerted us to al-'Aynî’s (1360-1451) account of the plague in Samarqand based on his father's testimony.
} 
Clearly, the Islamic tradition, far more than other societies that had suffered the devastations of the Justinianic Plague, was adept at recognizing plague and marking its chronology $9{ }^{97}$ But plague, for them, was a 'strike', a crisis of limited duration. The litanies of plague outbreaks were not attempts to draw connections between epidemics, but a record to show that God repeatedly tested his faithful with comparable challenges. For post-Black Death Syro-Egyptian writers, the 1250s had presented the community with a test of apocalyptic proportions in the guise of the Mongol conquests and the destruction of the caliphate in Baghdad. This event was so immense and traumatic that it simply occluded continued engagement with an epidemic outbreak of limited duration and geographic extent.

The erasure of the 1258 outbreak thus stands as an exception in an otherwise remarkable Islamic historiographical tradition of plague. In the context of the present COVID-19 pandemic, many eyes have turned on the 1918 Flu Pandemic, which Alfred Crosby famously called 'forgotten' in United States historiography. ${ }^{98}$ America, and much of the world, was just issuing from the Great War. Is there something about the combination of epidemics and the trauma of war that produces a special kind of amnesia? That is a question far beyond what the present study can answer. But the combined evidence we have presented suggests that it is one worth posing.

Acknowledgements. The authors would like to thank the following for their assistance in the genesis of this study: Stuart Borsch, Francesco Calzolaio, Matthew Melvin-Koushki, Justin Stearns and Nükhet Varlık. The work would also not have been possible without digital access to Arabic texts on Alwaraq.net, Shamela and Archive.org.

Conflicts of interests. The authors declare no conflicts of interest.

\footnotetext{
${ }^{97}$ On the creation of a cultural memory of the Justinianic Plague in western Europe, see Michael McCormick, 'Gregory of Tours on Sixth-Century Plague and Other Epidemics,' Speculum, 96, 1 (2021), 38-96. Gregory was indeed an influential writer in later medieval Europe, but there is little evidence that traditions of 'plague thinking' developed either in Christian theology or Latin medicine before the resurgence of plague in Europe in the fourteenth century.

${ }^{98}$ Alfred W. Crosby, America's Forgotten Pandemic: The Influenza of 1918, 2nd edn. (New York: Cambridge University Press, 2003). This originally appeared as Epidemic and Peace, 1918 (Westport, CT; London: Greenwood Press, 1976).
} 